\title{
Investigation on Conversion Pathways in Degradative Solvent Extraction of Rice Straw by Using Liquid Membrane-FTIR Spectroscopy
}

\author{
Watcharakorn Ketren ${ }^{1, *(\mathbb{D})}$, Heishun Zen ${ }^{1}$, Ryuichi Ashida ${ }^{2}$, Toshiteru Kii ${ }^{1}$ and \\ Hideaki Ohgaki ${ }^{1}$ (D) \\ 1 Institute of Advanced Energy, Kyoto University, 611-0011 Kyoto, Japan; zen@iae.kyoto-u.ac.jp (H.Z.); \\ kii@iae.kyoto-u.ac.jp (T.K.); ohgaki.hideaki.2w@kyoto-u.ac.jp (H.O.) \\ 2 Graduate School of Engineering, Kyoto University, 615-8510 Kyoto, Japan; ashida@cheme.kyoto-u.ac.jp \\ * Correspondence: wacharakorn@gmail.com
}

Received: 3 December 2018; Accepted: 3 February 2019; Published: 7 February 2019

check for updates

\begin{abstract}
Degradative solvent extraction (DSE) is effective in both dewatering and upgrading biomass wastes through the selective removal of oxygen functional groups. However, this conversion mechanism has yet to be elucidated. Here, liquid membrane-FTIR spectroscopy was utilized to examine the main liquid product (Solvent-soluble) without sample modification. Rice straw (RS) and 1-methylnaphthalene (as a non-hydrogen donor solvent) were used as materials, and measurements were performed at treatment temperatures of $200,250,300$, and $350{ }^{\circ} \mathrm{C}$ for $0 \mathrm{~min}$, and at $350{ }^{\circ} \mathrm{C}$ for $60 \mathrm{~min}$. The Solvent-soluble spectra were quantitatively analyzed, and changes in the oxygen-containing functional groups and hydrogen bonds at each temperature were used to characterize the DSE mechanism. It was determined that the DSE reaction process can be divided into three stages. During the first stage, $200-300{ }^{\circ} \mathrm{C}(0 \mathrm{~min})$, oxygen was removed via dehydration, and aromaticity was observed. In the second stage, $300-350{ }^{\circ} \mathrm{C}(0 \mathrm{~min})$, deoxygenation reactions involving dehydration and decarboxylation were followed by reactions for aromatization. For the third stage, $350{ }^{\circ} \mathrm{C}(0-60 \mathrm{~min})$, further aromatization and dehydration reactions were observed. Intramolecular reactions are indicated as the predominant mechanism for dehydration in RS DSE, and the final product is composed of smaller molecular compounds.
\end{abstract}

Keywords: biomass; degradative solvent extraction; dewater; Fourier Transform Infrared (FTIR); rice straw; upgrade

\section{Introduction}

The increased consumption and possible exhaustion of fossil fuel resources are directly related to a variety of environmental and economic problems on both global and regional scales. To address these problems, the use of renewable energy has increased, and its development and optimization are the keys for future energy solutions [1,2]. Biomass is a promising renewable energy resource due to its carbonaceous nature [3]. Renewable biomass, such as energy crops and agricultural wastes, are widely used as biofuels and are representative of future fuel resources [4,5]. Biomass can be converted to fuels, as well as other chemicals and materials, through biochemical or thermochemical processes. The main thermochemical techniques used in processing biomass include combustion, gasification, hydrothermal liquefaction, and pyrolysis [6-8]. Notably, biomass materials are generally rich in oxygen content, possess low bulk density, and have relatively low calorific heating values. Compared to coal, biomass has a lower thermal content, higher moisture content, lower bulk density, and its physical form is neither homogeneous nor free-flowing, which usually makes biomass unusable without further processing $[9,10]$. 
Pretreatment that results in the removal of water from biomass is necessary prior to its use in any thermal conversion processes. The degradative solvent extraction (DSE) method has been used successfully to dewater and upgrade low-rank coals [11-15] and biomass [16-18] under mild conditions. In DSE, low-rank coal and biomass are treated in a nonpolar solvent in a batch autoclave reactor at around $350{ }^{\circ} \mathrm{C}$ under pressure. Samples are then fractionated and filtrated into three products at room temperature, which are called "Soluble", "Deposit", and "Residue". Soluble and Deposit are extracted products, while Residue is the unextracted product. The method is able to upgrade low-rank coal and biomass through the selective removal of oxygen functional groups in the form of $\mathrm{H}_{2} \mathrm{O}$ or $\mathrm{CO}_{2}[10,16,19]$. The Soluble fraction has a high carbon content (81-83.3 wt.\%), a low oxygen content, and is almost completely free from ash [16]. In addition, it can be utilized as a precursor of carbon fiber. It is worth noting that this method has also been successful in dewatering and upgrading coal [20] and biomass wastes [21]. Researchers have studied the reaction process in order to optimize the treatment conditions. The main reactions in the DSE process have been identified as thermal extraction, deoxygenation, decarboxylation, and aromatization $[16,18]$. Further investigation also identified deoxygenation and slight aromatization reactions during an isothermal stage at $350{ }^{\circ} \mathrm{C}$ [18]. The intermolecular dehydration reactions of cellulose are significantly suppressed. The bond cleavage reactions proceed in parallel with intramolecular dehydration reactions, which results in more unsaturated double bonds [22]. However, the mechanism of DSE is still not yet fully understood.

Infrared (IR) spectroscopy is a non-destructive technique and can measure many forms of sample, such as solid, liquid, and gas. Several methods have been proposed in order to obtain the IR spectrum of carbonaceous materials, such as coal [23-26] and biomass [27-32]. For the qualitative and quantitative determination of biomass components, Fourier Transform Infrared (FTIR) spectroscopy is a rapid technique and is commonly used to obtain the IR spectra for coal [33]. In order to understand the chemical composition and structure of biomass, FTIR spectroscopy has been implemented for the main components of biomass, which are cellulose [34,35], lignin [36], and hemicellulose [37]. Most samples of biomass for FTIR are in the solid-state pellet form. However, interference due to the background spectrum of absorbed water limits peak characterization analysis.

Investigations concerning the mechanism of DSE have been performed in previous studies [16, 18]. To identify structural components of products and to understand the reaction process of DSE, researchers analyzed the composition of the solid and gas states of the initial reactant and final products $[16,18]$. However, since the degradative solvent extraction process (DSE) involves thermal decomposition, the reaction process and products are complex, and analysis of the analytes under the same conditions as those of the DSE system is required for accurate characterization. Therefore, analysis techniques that can be performed without physical or chemical modification of the sample are preferable in order to avoid interfering with and contaminating the sample. Our proposed technique in this study is to analyze the liquid state (the "Solvent-soluble") under the same conditions as those of the DSE system.

A liquid cell for FTIR measurement has been applied previously in characterizing liquid hydrocarbon fuel $[38,39]$ and in characterizing liquid organic compounds [40,41]. This type of liquid solution analysis, however, is challenging due to the complex compositions of the samples.

To acquire acceptable IR spectra of the analyte in the liquid state, special types of liquid cells were developed for this purpose. The technique, which uses liquid cells for absorption measurement, called liquid membrane-FTIR, has been shown to be a suitable and reproducible technique for the characterization and quantitative analysis of the Solvent-soluble of rice straw (RS) [42]. The use of liquid membrane-FTIR was proposed to interpret the main mechanism of the DSE of RS in a previous study [43]. However, the FTIR spectra of that study were too noisy, and deconvolution of the overlapping peaks was not possible. This study has improved the experimental conditions to reduce the noise in the water vibrational region. The newly obtained IR spectra provided good reproducibility and improved peak resolution. This was helpful in the quantitative analysis of the spectral regions related to the oxygenic functional groups and allowed for further clarification of the process mechanism of DSE for RS. 
The hydrogen bonding interaction in biological chemistry is identified as crucial and has been a challenging study [44-50]. IR spectroscopy has proved to be a promising means of quantifying the hydrogen-bonding interaction in coal [46,51,52] and biomass [53-56]. There is a nearly linear relationship between the wavenumber shift from the free hydroxyl-stretching vibration, $\Delta v_{\mathrm{OH}}$, and that of the enthalpy change of hydrogen bonds, $\Delta \mathrm{H}$, related to the $\mathrm{OH}$-stretching region. This relationship was proposed by Drogo et al. [44]. The enthalpy change of hydrogen bond formation has been used by many investigators to interpret the average strength of hydrogen bonds [45,57]. Miura et al. [47-49] developed the method based on this relationship, to calculate the amounts of individual hydrogen bonds and estimate the strength distribution of hydrogen bonds in coal. Furthermore, this method was applied to study the dewatering mechanism of coal [58]. Based on the analytical chemistry results of the Solvent-soluble of biomass, such as the rational formula of $\mathrm{CH}_{0.894-1.062} \mathrm{O}_{0.065-0.114}$, it was almost completely free from ash and had high heating values (HHV) as high as $34.1-37.2 \mathrm{MJ} / \mathrm{kg}$, so its properties were judged to be comparable to sub-bituminous coal [16]. Thus, the method for the investigation of hydrogen bonds in coal suggests a method to study the behaviors of different kinds of hydrogen bonds in the Solvent-soluble of RS during the solvent treatment on the basis of the DSE of biomass. Understanding the evolution of hydrogen bonding in the Solvent-soluble of RS during solvent treatment could give insights into the mechanism of DSE.

This paper aims at a better understanding of the transformation of oxygen-containing functional groups during the DSE and the elucidation in detail of the reaction pathway. In addition, the amount of hydroxyls contributing to each hydrogen bond and the bond strength values were first investigated to discuss the dewatering mechanism of the DSE of RS.

\section{Materials and Methods}

\subsection{Batch Degradative Solvent Extraction}

\subsubsection{Materials and Solvent Used}

Rice straw (RS) was used as a biomass sample. RS biomasses were prepared using a Wonder crusher (WC-3 model, Osaka Chemical Co. Ltd., Osaka, Japan) and testing sieves (Tokyo Screen Co. Ltd., Tokyo, Japan), with 425 and $150 \mu \mathrm{m}$ apertures used subsequently to select samples of suitable

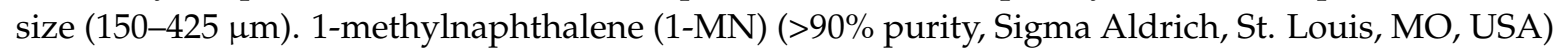
was used as a solvent for the degradative solvent extraction process. This solvent is well known as a non-hydrogen donor solvent and a non-polar solvent. It also does not react with biomass samples at about $350{ }^{\circ} \mathrm{C}$, which was previously verified in a detailed analysis of brown coal that used 1-MN as a solvent. [59]. The schematic diagram and apparatus used for DSE in this study are shown in Figure 1.

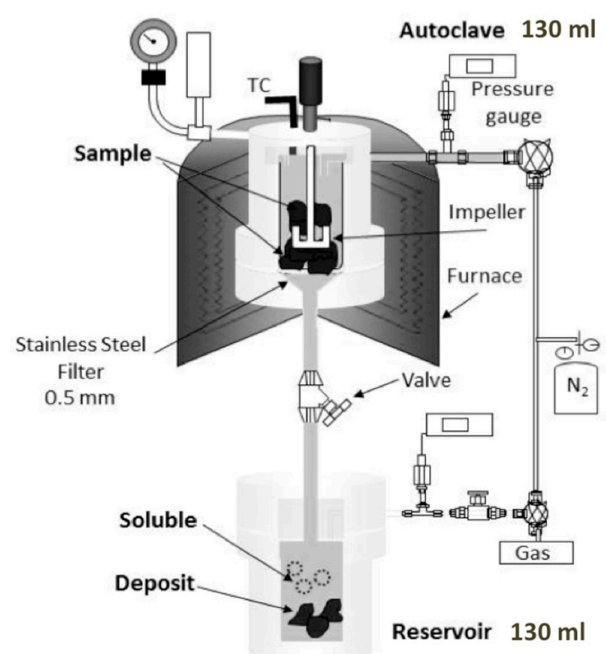

Figure 1. Schematic diagram of degradative solvent extraction (DSE) system. 


\subsubsection{Degradative Solvent Extraction Experiment (DSE)}

The treatment was performed in a $130 \mathrm{~mL}$ stainless steel autoclave reactor. A stainless steel filter with an outer diameter of $65 \mathrm{~mm}$ and $0.5 \mu \mathrm{m}$ apertures was fitted at the lower end of the reactor. A $130 \mathrm{~mL}$ stainless steel reservoir was connected at the bottom of the reactor using a ball valve. Helium gas was purged at $0.5 \mathrm{MPa}$ into the reactor and reservoir several times on each run in order to be sure that there was no oxygen in the system. Approximately 6 grams of dry, ash-free (d.a.f) RS sample and $80 \mathrm{~mL}$ of 1-MN solvent were carefully delivered into the reactor and heated up to the investigation treatment temperature using an electric furnace at a constant rate of $5^{\circ} \mathrm{C} / \mathrm{min}$. An agitator in the reactor, connected to a magnet-driven impeller, was used to continuously stir the sample throughout the treatment process.

Batch extractions were performed at 200, 250, 300, and $350{ }^{\circ} \mathrm{C}$ for $0 \mathrm{~min}$, and at $350{ }^{\circ} \mathrm{C}$ for $60 \mathrm{~min}$. When the furnace reached the desired temperature, it was stopped, and the connecting valve was opened immediately, allowing the extracted products into the reservoir. The autoclave and the reservoir were then allowed to cool down to room temperature. The high-molecular weight compounds that remained in the autoclave reactor were the unextracted products, called "Residue". The extracted products were the solid extracted precipitate at room temperature, called "Deposit", and the extracted soluble at room temperature, called the "Solvent-soluble" (liquid phase). The fraction of water and the smallest molecular weight compounds that dissolved in the solvent are referred to as "Liquid". The Solvent-soluble was the product that was analyzed in this study. The Solvent-soluble and Deposit were separated by vacuum filtration using a $0.5 \mu \mathrm{m}$ polytetrafluorothylene (PTFE) filter. The process described above was used for each treatment temperature.

Regarding the selected treatment temperatures, the thermogravimetric (TG) curve of the RS was tested to observe the thermal decomposition behavior of RS from 0 to $400{ }^{\circ} \mathrm{C}$, as shown in Figure A1. The TG curve of the RS showed that the sample weight decreased mainly at temperatures between 200 and $400{ }^{\circ} \mathrm{C}$. The maximum weight reduction was at around $278^{\circ} \mathrm{C}$. Therefore, treatment temperatures were selected from between 200 and $350{ }^{\circ} \mathrm{C}$, since $350{ }^{\circ} \mathrm{C}$ was identified previously as the optimal temperature for RS DSE [16,17].

\subsection{Liquid Membrane-FTIR}

Fourier Transform Infrared (FTIR) spectra of Solvent-soluble were recorded from 4000 to $400 \mathrm{~cm}^{-1}$. Sixty-four scans were acquired at a $2 \mathrm{~cm}^{-1}$ resolution on a JEOL spectrometer (JIR-WINSPEC50 model, JEOL Ltd., Tokyo, Japan) using the liquid membrane-FTIR technique. Calcium fluoride $\left(\mathrm{CaF}_{2}\right)$ was chosen for the liquid cells for IR absorption measurements in this study due to its non-hygroscopic property. A transmission range of $50000-1025 \mathrm{~cm}^{-1}$ covers the region of the study. The other liquid cells, compared to $\mathrm{CaF}_{2}$, are suitable for quantitative analysis of the studied sample, such as $\mathrm{KBr}$ and $\mathrm{NaCl}$ which have high water solubility, or $\mathrm{BaF}_{2}$ and $\mathrm{ZnS}$ which result in the spectral dispersion [60-62]. All experiments were performed at room temperature. A lead metal sheet with a $0.05 \mathrm{~mm}$ thickness and a $22 \times 10 \mathrm{~mm}^{2}$ rectangular area was used as a spacer. The measurement procedure was similar to the study by Watcharakorn et al. [42]. About $2.5 \mathrm{~L} / \mathrm{min}$ of nitrogen gas was continuously purged through the measuring compartment in order to eliminate moisture. The Solvent-soluble samples of RS of each batch extracted from DSE were analyzed using liquid membrane-FTIR measurement.

Each measurement of the background spectrum of the air was collected immediately before collecting the single-beam spectrum. The measurement spectrum was divided into two regions: The -OH (3650-3100 $\left.\mathrm{cm}^{-1}\right)$ and oxygen-containing $\left(1850-1500 \mathrm{~cm}^{-1}\right)$ regions. From the RS spectrum, first the 1-MN spectrum was subtracted as a solvent background. Since a change in the reflectance of the samples resulted when the baseline of the spectra changed with the treatment temperature, a baseline correction was performed as follows: A straight line was drawn through two points passing two absorption minima at around 3650 and $3150 \mathrm{~cm}^{-1}$ for the $\mathrm{OH}$-stretching region, and at around 1870 and $1500 \mathrm{~cm}^{-1}$ for the oxygen-containing region. The IR spectrum was deconvoluted after the baseline variation was corrected. The software Igor Pro 7 (Version 7.08, WaveMetrics Inc., Lake Oswego, OR, 
USA) was used for processing the spectrum, using a multi-peak fit function with the least squares fitting algorithm. A Gaussian distribution was used as the peak shape [23-28]. The number, sub-peak position, peak width, and their variation ranges were assigned as in Table A1. These values were obtained from previous FTIR analysis of coal and biomass [49,63-70], and were used to perform peak deconvolution. The band assignment in the $\mathrm{OH}$-stretching region and the nine bands in the oxygen-containing region (anhydride, ester, aldehydes, carboxyl groups, conjugated carbonyl groups, etc.) were assigned to resolve the raw spectra. The integrated peak areas of each functional group were obtained from the derived peaks by fitting until convergence with the original curve was nearly achieved.

To ensure the reliability and reproducibility of the method employed, each sample was prepared and analyzed through seven samplings. The standard deviations for the peak areas of the functional groups at the different treatment temperatures were calculated for both the $\mathrm{OH}$-stretching region and the oxygen-containing region, and the chi-squared value was calculated to measure goodness of fit. The contribution of the functional groups to the form in each region of the spectrum was calculated by taking the integral of absorbance of the band as $100 \%$ on the basis of curve fitting.

\subsection{Quantitative Analysis of the Change in Hydrogen Bonding during Solvent Extraction}

The estimation of the strength distribution of hydrogen bonds was examined in the main region of hydrogen bonding in the hydroxyl region $[49,63]$. The curve fitting method was used to divide the FTIR spectra into the following $\mathrm{OH}$ bands: $\mathrm{OH}-\pi$, self-associated $\mathrm{OH}, \mathrm{OH}-$ ether, tightly bound cyclic $\mathrm{OH}$ tetramers, $\mathrm{OH}-\mathrm{N}, \mathrm{COOH}$ dimers and free $\mathrm{OH}$ (if it is present), $\mathrm{CH}$ stretching (three separate bands), aromatic hydrogen, and aliphatic hydrogen (two separate bands) [49,63]. In this work, $\mathrm{OH}-\mathrm{N}, \mathrm{COOH}$ dimer, and three of the $\mathrm{CH}$ stretching bands were not observed due to the effect of interference of the solvent, which will be described in the section on the FTIR study. The IR spectra of the RS Solvent-soluble at each treatment temperature obtained from liquid membrane-FTIR were peak-resolved using the same method as in considering the changes of the functional groups during solvent treatment. The amount of hydroxyls contributing to each hydrogen bond, $n_{\mathrm{OH}, j}$, was estimated based on Beer's law by Equation (1), where $A_{j}$ is the peak area of $\mathrm{OH}$ for the $j$ th peak, $\alpha_{\mathrm{OH}, 0}$ is the absorptivity of the stretching vibration of the free $\mathrm{OH}$, and $\Delta v_{\mathrm{OH}, j}$ is the wavenumber shift of $\mathrm{OH}$ in hydrogen bonds relative to the position of free $\mathrm{OH}$ groups $\left(3611 \mathrm{~cm}^{-1}\right)$. The $\alpha_{\mathrm{OH}, 0}$ value used to calculate the amount of $\mathrm{OH}$ was estimated referring to the slope of the free $\mathrm{OH}$ calibration curve with their concentrations, as in the previous study [42]. The total amount of $\mathrm{OH},\left(n_{\mathrm{OH}}\right)_{\text {total }}$, related to each absorption band can be calculated by Equation (2).

$$
\begin{gathered}
n_{\mathrm{OH}, j}=A_{j} /\left\{\alpha_{\mathrm{OH}, 0}\left(1+0.0147\left(\Delta v_{\mathrm{OH}, j}\right)\right)\right\}\left(\mathrm{mg}-\text { soluble } \cdot \mathrm{mL}^{-1}-1 \mathrm{MN}\right) \\
\left(n_{\mathrm{OH}}\right)_{\mathrm{total}}=\sum_{j} n_{\mathrm{OH}, j}\left(\mathrm{mg}-\text { soluble } \cdot \mathrm{mL}^{-1}-1 \mathrm{MN}\right)
\end{gathered}
$$

When the bond formed is stronger, the IR wavenumber of $\mathrm{OH}$-stretching vibration shifts to a lower wavenumber and releases energy $(\Delta \mathrm{H}<0)$. The enthalpy change, $\Delta \mathrm{H}$, has been interpreted as the strength of the hydrogen bonds by many investigators $[44,57]$. The strength of each hydrogen bond was estimated by the relationship between the enthalpy change of formation, $\Delta \mathrm{H}$, and the $\mathrm{OH}$ wavenumber shift, $\Delta v_{\mathrm{OH}}$, known as 'the linear enthalpy-spectroscopic shift relations' obtained by Drago et al. [44]. The strength of the $j$ th hydrogen bonds was calculated by Equation (3), and the total enthalpy for the formation of all $\mathrm{OH}$-associated hydrogen bonds $(-\Delta \mathrm{H})_{\text {total }}$ was calculated using Equation (4) [49].

$$
\begin{gathered}
(-\Delta \mathrm{H})_{j}=0.067\left(\Delta v_{\mathrm{OH}, j}\right)+2.64\left(\mathrm{~kJ} \cdot \mathrm{mol}^{-1}\right) \\
(-\Delta \mathrm{H})_{\mathrm{total}}=\sum_{j} n_{\mathrm{OH}, j}(-\Delta \mathrm{H})_{j}\left(\mathrm{~kJ} \cdot \mathrm{mol}^{-1}\right)
\end{gathered}
$$




\section{Results and Discussion}

The suitability of liquid membrane-FTIR spectroscopy for use in analyzing the chemical structure of the RS Solvent-soluble was demonstrated previously through the quantitative measurement of the oxygen content in the $\mathrm{OH}$-stretching region [42]. The oxygen content values that were obtained using liquid membrane-FTIR were in agreement with other published values for the DSE of RS [16]. The reliability of the technique was also previously demonstrated, as the measured bias between measurement groups was found to be almost zero [42]. The technique has also been used in successfully identifying the overall process mechanism for RS DSE [43].

For further clarification of the reaction pathway and improved understanding of the DSE process, the liquid membrane-FTIR spectroscopy technique was employed again in this study under modified experimental conditions to obtain IR spectra with improved resolution for the RS Solvent-soluble from DSE. Quantitative analyses of these spectra were used to study the evolution of the functional groups and to observe changes to the hydrogen bonding of the Solvent-soluble during the solvent treatment. The spectra for the background solvent, 1-MN, were subtracted from the as-measured spectra, and a baseline correction was performed over the regions of interest. The $\mathrm{OH}$-stretching region and the carbonyl region were measured due to their relationship with the oxygenic functional groups. The peak assignments are listed in Table A1. Overlapping peaks and the peak areas of different functional groups were deconvoluted and determined using Igor Pro 7.

\subsection{FTIR Spectra of the Solvent-Soluble of Rice Straw}

Figure 2a illustrates the broad spectrum of the raw RS obtained from the conventional $\mathrm{KBr}$ pellet. The $\mathrm{O}-\mathrm{H}$ stretching region $\left(3600-3100 \mathrm{~cm}^{-1}\right)$, the $\mathrm{C}-\mathrm{H}$ stretching region $\left(3000-2800 \mathrm{~cm}^{-1}\right)$ and the $\mathrm{C}-\mathrm{O}, \mathrm{C}-\mathrm{OH}$, and $\mathrm{C}-\mathrm{O}-\mathrm{C}$ stretching bands of cellulose $\left(1100-1000 \mathrm{~cm}^{-1}\right)$ were identified and assigned based on published data [16]. The spectrum for 1-MN, shown in Figure 2b, exhibited the aromatic $\mathrm{C}-\mathrm{H}$ stretching band at $3047 \mathrm{~cm}^{-1}$, the aliphatic $\mathrm{C}-\mathrm{H}$ stretching band at $2980-2870 \mathrm{~cm}^{-1}$, as well as a weak band at $3009 \mathrm{~cm}^{-1}$. The spectrum also displayed the $\mathrm{C}-\mathrm{C}-\mathrm{H}$ in-plane ring bending region (1300-100 $\left.\mathrm{cm}^{-1}\right)$ and the $\mathrm{C}-\mathrm{H}$ in-plane bending vibration region $\left(1420-1128 \mathrm{~cm}^{-1}\right)$. The spectra of the Solvent-soluble obtained at each batch extraction are shown in Figure 3. The figure shows the IR spectra of the Solvent-soluble of RS prepared at 200, 250, 300, and $350^{\circ} \mathrm{C}$ with residence time 0 min, and at $350{ }^{\circ} \mathrm{C}$ with residence time $60 \mathrm{~min}$. The spectra characteristics are analogous to the spectrum of $1-\mathrm{MN}$. The Solvent-soluble spectra were different from those for the raw RS in that the Solvent-soluble spectra displayed weakened $\mathrm{OH}$-stretching bands, more distinct bands for aromatic $\mathrm{C}-\mathrm{H}$ stretching at $3050 \mathrm{~cm}^{-1}$, aliphatic $\mathrm{C}-\mathrm{H}, \mathrm{C}-\mathrm{H}_{2}$, and $\mathrm{C}-\mathrm{H}_{3}$ stretching at $2960-2850 \mathrm{~cm}^{-1}$, and $\mathrm{C}=\mathrm{O}$ stretching at $1700 \mathrm{~cm}^{-1}$, as well as other peaks associated with bond deformation at $1500-1000 \mathrm{~cm}^{-1}$ [16]. The oxygen-containing region $\left(1800-1500 \mathrm{~cm}^{-1}\right)$ increased with the solvent treatment temperature from 200 to $300{ }^{\circ} \mathrm{C}$, and decreased when the treatment temperature changed from 300 to $350{ }^{\circ} \mathrm{C}$. The peak related to the $\mathrm{C}-\mathrm{H}$ band of the Solvent-soluble displayed significant overlap between the different samples due to the strong $\mathrm{C}-\mathrm{H}$ band for 1-MN. In order to overcome this interference of the background sample, the quantitative analysis in this study was performed for the absorbance region in between 3600 and $3100 \mathrm{~cm}^{-1}$ for the oxygen-hydrogen $(-\mathrm{OH})$ stretching region, and 1800 and $1500 \mathrm{~cm}^{-1}$ for the oxygen-containing region. 


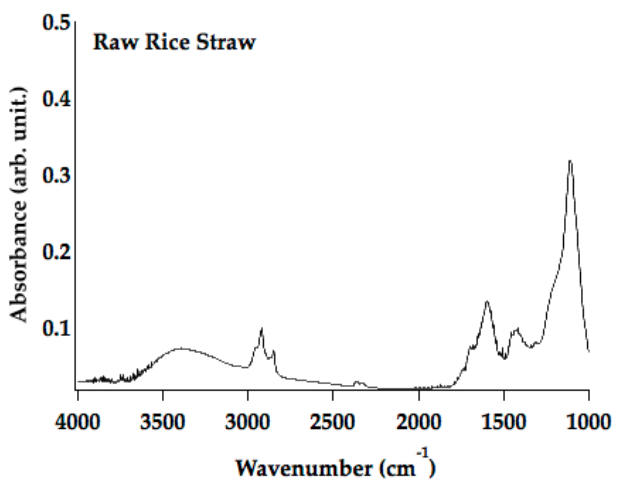

(a)

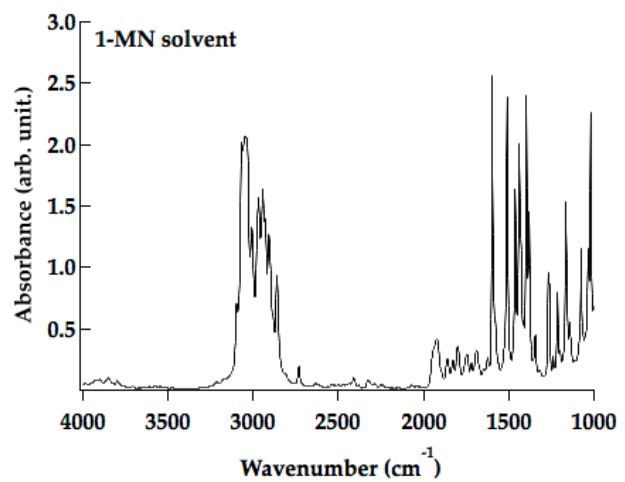

(b)

Figure 2. FTIR spectra of (a) the raw rice straw (RS) obtained by the conventional KBr pellet and (b) 1-methylnaphthalene (1-MN) solvent obtained by liquid membrane-FTIR.

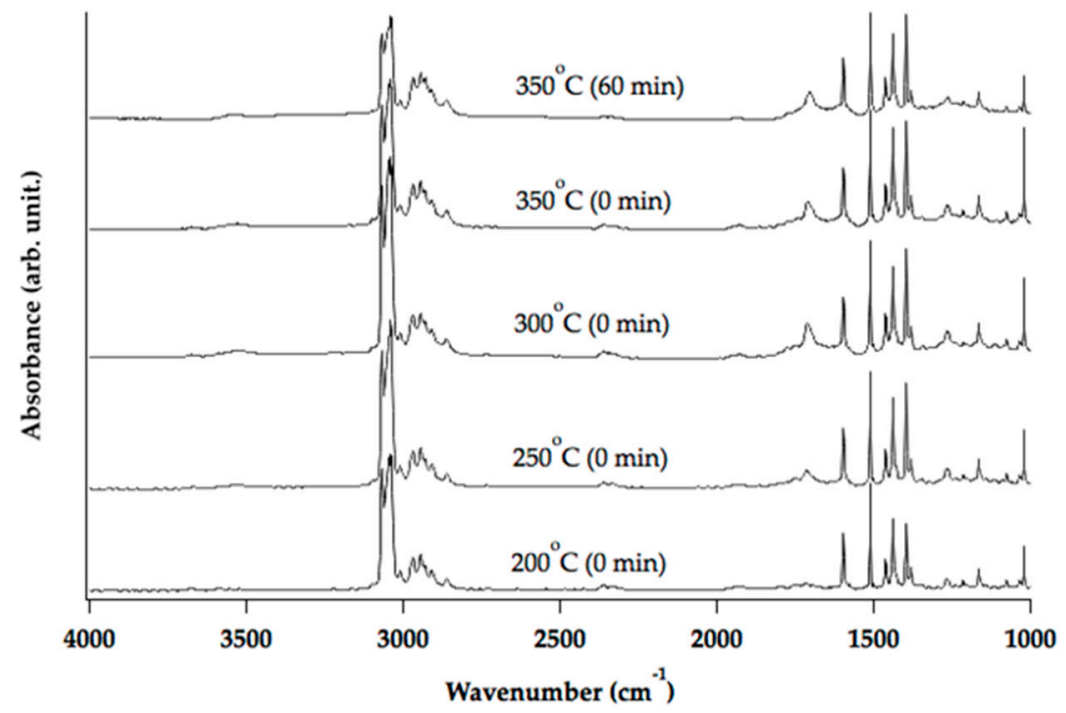

Figure 3. FTIR spectra of the Solvent-soluble obtained at 200, 250, 300, and $350{ }^{\circ} \mathrm{C}$ with residence time $0 \mathrm{~min}$, and at $350^{\circ} \mathrm{C}$ with residence time $60 \mathrm{~min}$.

\subsection{Quantitative Analysis of the IR Spectra of the Solvent-Soluble of Rice Straw}

\subsubsection{Changes of the Functional Groups during Solvent Treatment}

The adjusted measurement conditions resulted in smoother FTIR spectra, reduced deviation in the wavenumber shift relative to the initial peak of the region, and increased precision in the identification of the two absorption minima required for baseline correction. The curve-fitting results were successfully achieved with small chi-square values.

Figure 4 a shows the $\mathrm{OH}$ bands in the $\mathrm{OH}$-stretching region $\left(3650-3100 \mathrm{~cm}^{-1}\right)$. The wide band centered at around $3400 \mathrm{~cm}^{-1}$ was attributed to the hydrogen bonding of the self-associated $\mathrm{OH}$ $\mathrm{n}$-mers and the distinct peak at $3540 \mathrm{~cm}^{-1}$ was attributed to $\mathrm{OH}-\pi$ hydrogen bonding. The other two hydrogen bonds identified in the spectra were for the $\mathrm{OH}$-ether $\mathrm{O}$ functional group and for the tightly bound cyclic-OH tetramers at 3280 and $3170 \mathrm{~cm}^{-1}$, respectively. Curve-fitting was successfully used to identify peaks in the oxygen-containing region from 1850 to $1500 \mathrm{~cm}^{-1}$. Figure $4 \mathrm{~b}$ shows the bands for the nine oxygenic functional groups identified in this region. The strongest absorption band $\left(1710 \mathrm{~cm}^{-1}\right)$ was attributed to carboxyl groups $(-\mathrm{COOH})$, while shoulder bands at 1800,1770 , and $1740 \mathrm{~cm}^{-1}$ were assigned to anhydrides (-COOCO), esters (-COO), and aldehydes (-COH), respectively. Weak bands relative to the carboxyl groups at 1670 and $1650 \mathrm{~cm}^{-1}$ were attributed to conjugated 
carbonyl structure groups $\left(-\mathrm{C}(\mathrm{O})_{2} \mathrm{O}\right)$. The band at $1607 \mathrm{~cm}^{-1}$ was attributed to aromatic $\mathrm{C}=\mathrm{C}$ bonds, while the peaks at 1580 and $1560 \mathrm{~cm}^{-1}$ were associated with aromatic stretching bands.

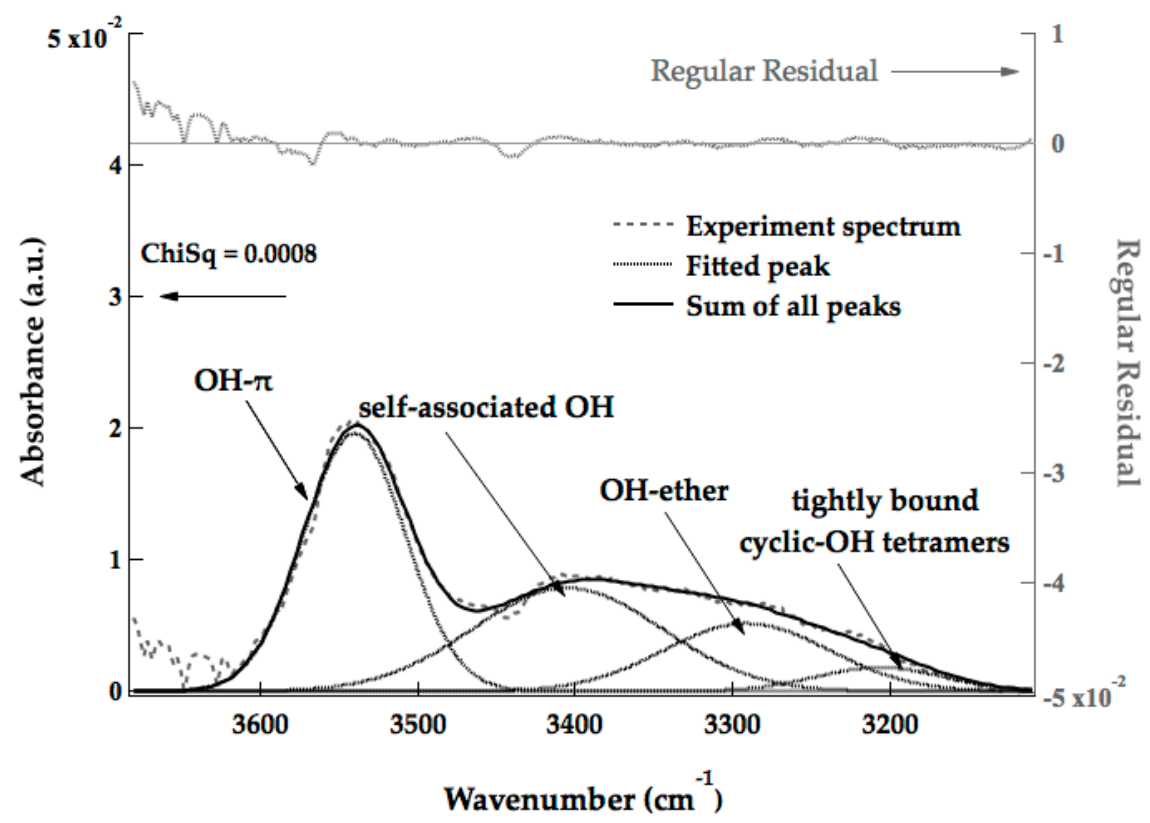

(a)

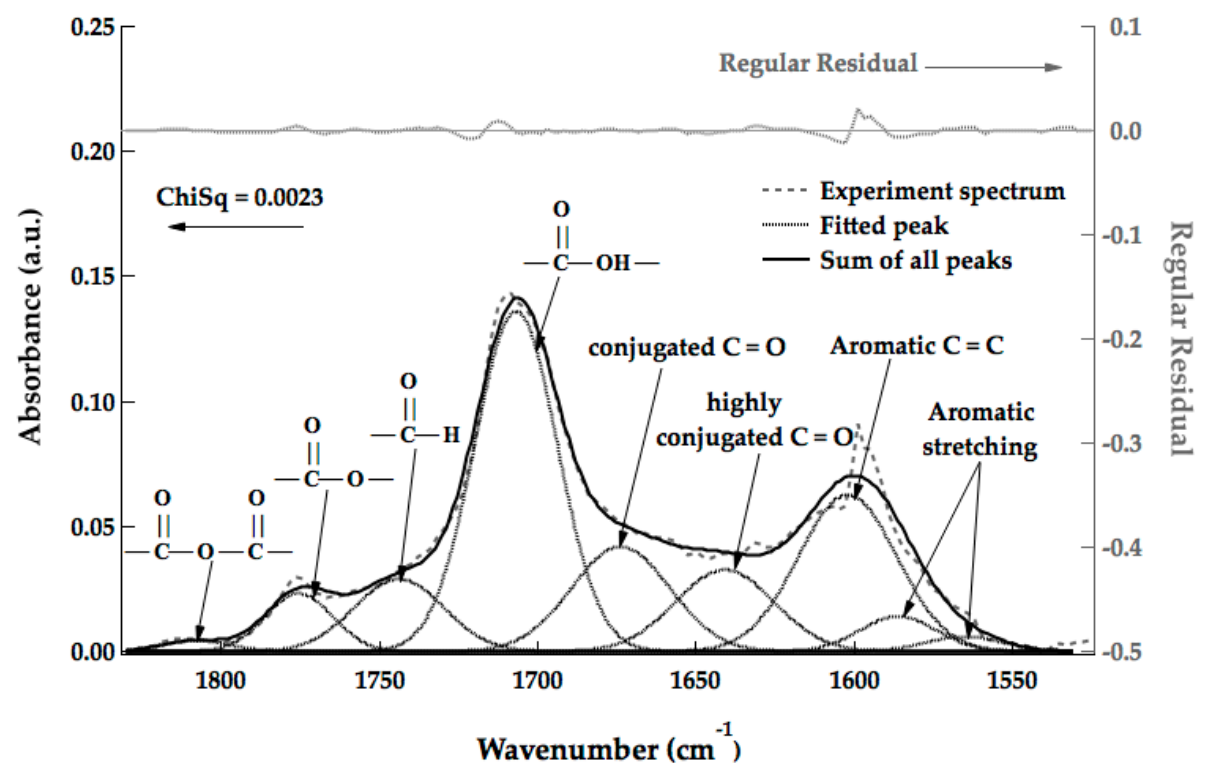

(b)

Figure 4. Curve-fitting of absorption bands by liquid membrane-FTIR of solvent soluble of RS at $350{ }^{\circ} \mathrm{C}$ treatment temperature with residence time $60 \mathrm{~min}$ : (a) The $\mathrm{OH}$-stretching region $\left(3650-3100 \mathrm{~cm}^{-1}\right)$, (b) the oxygen-containing region $\left(1850-1500 \mathrm{~cm}^{-1}\right)$.

Figure 5 illustrates the peak areas of the functional groups identified from the deconvolution of the FTIR spectra at each treatment temperature for both the $\mathrm{OH}$-stretching region $\left(3650-3100 \mathrm{~cm}^{-1}\right)$ and the oxygen-containing region $\left(1850-1500 \mathrm{~cm}^{-1}\right)$. The bar plots show the peak area values for the different functional groups in these regions. The summations of the peak areas for all the functional groups are displayed as solid lines, while the ratios of the total peak area to the weight percentage yield of the RS Soluble are shown as dashed lines. The Soluble solid fraction values after removal of the solvent were $0.56 \%, 1.13 \%, 1.68 \%, 1.77 \%$, and $1.86 \%$ at $200,250,300,350{ }^{\circ} \mathrm{C}(0 \mathrm{~min})$ and $350{ }^{\circ} \mathrm{C}$ (60 $\mathrm{min}$ ), respectively. Figure $5 \mathrm{a}$ shows the absorbance area of each hydroxyl functional group in 
the $\mathrm{OH}$-stretching region. Hydrogen bonds for $\mathrm{OH}-\pi$ and for the self-associated $\mathrm{OH}$ n-mers were observed from $200^{\circ} \mathrm{C}$, with the area for each group increasing up to $300^{\circ} \mathrm{C}$ and then decreasing at higher treatment temperature. The $\mathrm{OH}-$-ether hydrogen bonds were first measured at 300 and $350{ }^{\circ} \mathrm{C}$ ( $0 \mathrm{~min}$ ), while hydrogen bonds for the tightly bound cyclic-OH tetramers were found only at $350{ }^{\circ} \mathrm{C}$ (60 $\mathrm{min}$ ). The total peak area of hydrogen bonds at each temperature was found by summing the peak areas of the above groups. As the temperature increased from 200 to $300{ }^{\circ} \mathrm{C}$, the total peak area of hydrogen bonds relative to the yield of RS Soluble changed little. This suggests that, as the temperature increased, the measured increase in the Soluble quality was not the result of any increase in hydrogen bonds. Figure $5 \mathrm{~b}$ shows the peak area of the various functional groups in the oxygen-containing region (1800-1500 $\left.\mathrm{cm}^{-1}\right)$ at each treatment temperature. From 200 to $300^{\circ} \mathrm{C}$, an increase in the peak area was observed for carbonyl functional groups at 1800,1770, 1740, 1709, 1670, and $1650 \mathrm{~cm}^{-1}$. This indicates that carbonyl intermediate species in RS Solvent-soluble were formed during the solvent treatment. The aromatic $C=C$ band at $1600 \mathrm{~cm}^{-1}$ and those for aromatic stretching at 1580 and $1560 \mathrm{~cm}^{-1}$ were found to increase slightly at $200{ }^{\circ} \mathrm{C}$, and increased further at $30{ }^{\circ} \mathrm{C}$ and above. The peak areas of the carbonyl functional groups decreased from 300 to $350^{\circ} \mathrm{C}(0 \mathrm{~min})$. The percentage decreases in the peak areas for esters, highly conjugated carbonyls, aldehydes, carboxylic groups, and conjugated carbonyls from 300 to $350{ }^{\circ} \mathrm{C}$ (0 $\mathrm{min}$ ) were approximately $55.9 \%, 35.2 \%, 28.4 \%, 19.9 \%$, and $12.8 \%$, respectively. In contrast, anhydrides increased significantly from 300 to $350{ }^{\circ} \mathrm{C}(0 \mathrm{~min})$. From $350{ }^{\circ} \mathrm{C}(0 \mathrm{~min})$ to 350 ${ }^{\circ} \mathrm{C}$ (60 min), anhydrides, esters, carboxylic acids, and conjugated carbonyl functional groups decreased slightly, while aldehydes, highly conjugated carbonyl groups, aromatic $\mathrm{C}=\mathrm{C}$ bonds, and aromatic stretching bands were observed to increase slightly.

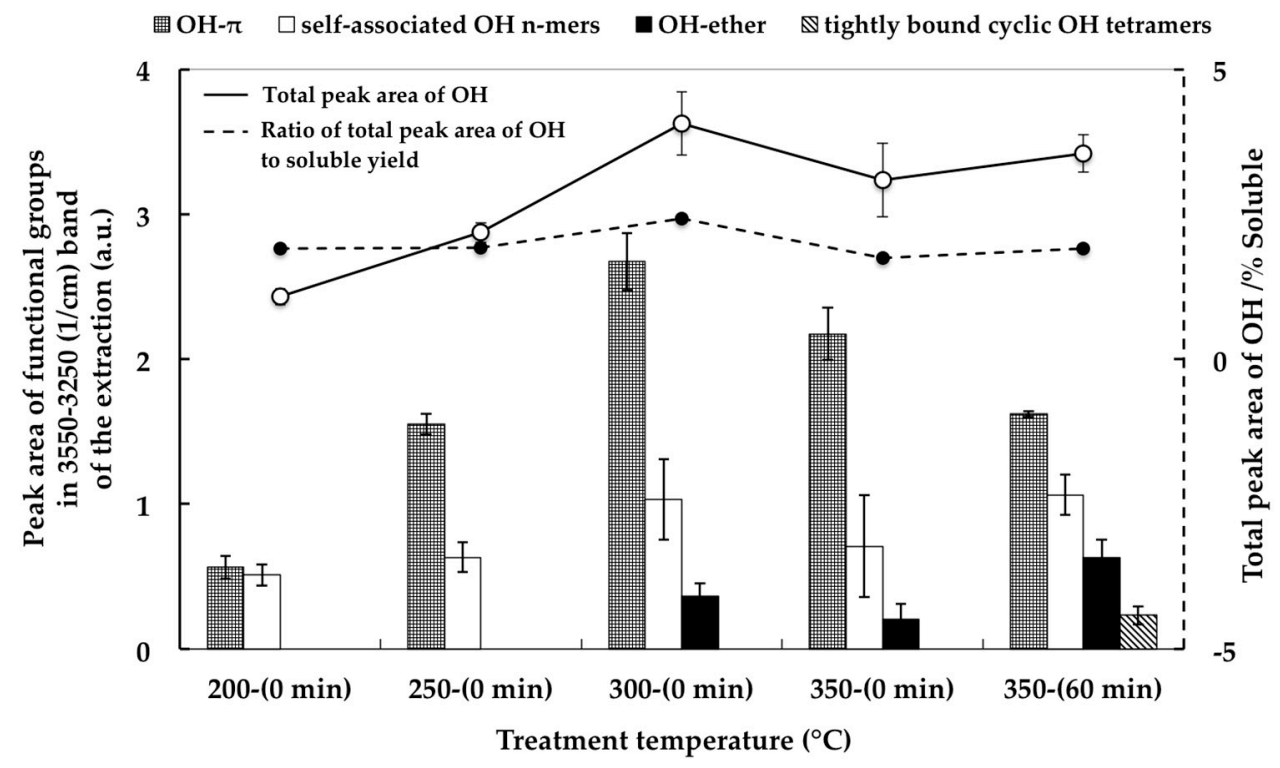

(a)

Figure 5. Cont. 


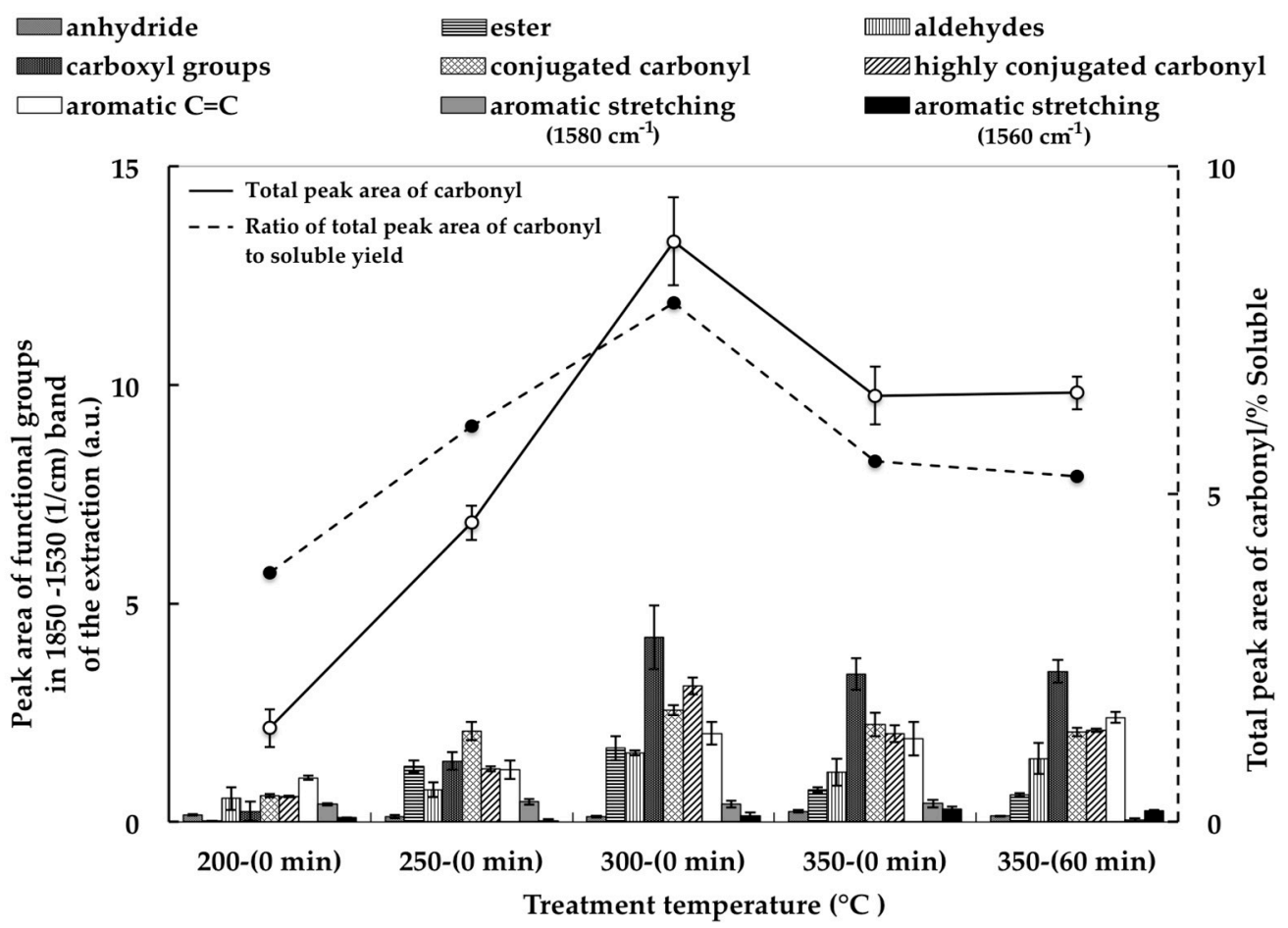

(b)

Figure 5. Peak areas for the different functional groups in (a) the $\mathrm{OH}$-stretching region $\left(3650-3100 \mathrm{~cm}^{-1}\right.$ ) and (b) the oxygen-containing region $\left(1850-1500 \mathrm{~cm}^{-1}\right)$ are illustrated as bar plots, with the standard error at $200,250,300,350{ }^{\circ} \mathrm{C}$ for $0 \mathrm{~min}$ and at $350{ }^{\circ} \mathrm{C}$ for $60 \mathrm{~min}$, and correspond to the left Y-axis. Solid lines show the total peak area for the combined functional groups in each region and also correspond to the left Y-axis. Dashed lines show the ratio of the total peak area to the RS Soluble yield and correspond to the right $\mathrm{Y}$-axis.

Wannapeera et al. previously reported on the generation of $\mathrm{CO}$ and $\mathrm{CO}_{2}$ in DSE from 300 to $350{ }^{\circ} \mathrm{C}$ [16]. The significant decreases in aldehydes, esters, conjugated carbonyls, and highly conjugated carbonyl groups between 300 and $350{ }^{\circ} \mathrm{C}$ not only signified the occurrence of deoxygenation, but also suggested the involvement of these groups in the release of $\mathrm{CO}$ and $\mathrm{CO}_{2}$. The significant reduction of the carboxylic groups from 300 to $350{ }^{\circ} \mathrm{C}(0 \mathrm{~min})$ also suggested the occurrence of decarboxylation. The appearance of a distinct anhydride peak at $350^{\circ} \mathrm{C}(0 \mathrm{~min})$ suggests the occurrence of dehydration, as Miura et al. linked the observation of anhydrides to the decomposition of hydrogen bonds for $\mathrm{COOH}$ dimers in the hydroxyl region for coal with the formation of water [49].

Table 1 shows the peak area ratio of the carboxylic groups $\left(1709 \mathrm{~cm}^{-1}\right)$ to the aromatic groups $\left(1600 \mathrm{~cm}^{-1}\right)$ at 300 and $350{ }^{\circ} \mathrm{C}(0 \mathrm{~min})$, and at $350{ }^{\circ} \mathrm{C}(60 \mathrm{~min})$. The ratio decreased both with increased treatment temperature and with increased residence time. Previous work by Zhu et al. [18] suggested a direct link between deoxygenation and the reduction of carboxylic groups and the increase in aromatic groups during solvent extraction. Combining the results from Table 1 with the observed changes to the active oxygen-containing functional groups, such as the hydroxyl groups which decreased from 300 to $350{ }^{\circ} \mathrm{C}(0 \mathrm{~min})$, suggests the occurrence of aromatization from 300 to $350{ }^{\circ} \mathrm{C}(0 \mathrm{~min})$.

Table 1. Peak area ratio of carboxylic groups to aromatic groups.

\begin{tabular}{cc}
\hline Treatment Temperature $\left({ }^{\circ} \mathbf{C}\right)$ & $\mathbf{C}=\mathbf{O} /$ Aromatic $\mathbf{C}=\mathbf{C}$ \\
\hline $300(0 \mathrm{~min})$ & 2.08 \\
\hline $350(0 \mathrm{~min})$ & 1.78 \\
\hline $350(60 \mathrm{~min})$ & 1.44 \\
\hline
\end{tabular}




\subsubsection{Changes of Hydrogen Bonding during Solvent Treatment}

Figure 6 shows the estimated amount and strength of the $\mathrm{OH}$-associated hydrogen bonds at each treatment temperature. The number of hydroxyl groups for each hydrogen bond, $\left(n_{\mathrm{OH}, j}\right)$, was estimated from each peak area, $A_{i}$, and the $\mathrm{OH}$ wavenumber shift, $\Delta v_{\mathrm{OH}}$, using Equation (1). The strength of each hydrogen bond was interpreted from the relationship between the enthalpy change, $\Delta \mathrm{H}$, and $\Delta v_{\mathrm{OH}}$ as shown in Equation (4). In terms of the estimated bond strength, the cyclic-OH was identified as the strongest of the four types of hydrogen bonds, followed by $\mathrm{OH}$-ether, the self-associated $\mathrm{OH}$ n-mers, and finally $\mathrm{OH}-\pi$, which had the weakest estimated bond strength. Only the weaker of the hydrogen bonds $(\mathrm{OH}-\pi$ and the self-associated $\mathrm{OH}$ n-mers) were observed at treatment temperatures of 200 and $250^{\circ} \mathrm{C}$. OH-ether was observed starting at $300{ }^{\circ} \mathrm{C}$, while the strongest of the four groups, cyclic-OH, was observed only at $350{ }^{\circ} \mathrm{C}$ during the prolonged residence time. This indicates that weaker hydrogen bonds were broken at lower treatment temperatures, while the breaking of stronger hydrogen bonding groups occurred only at increased treatment temperatures and times.
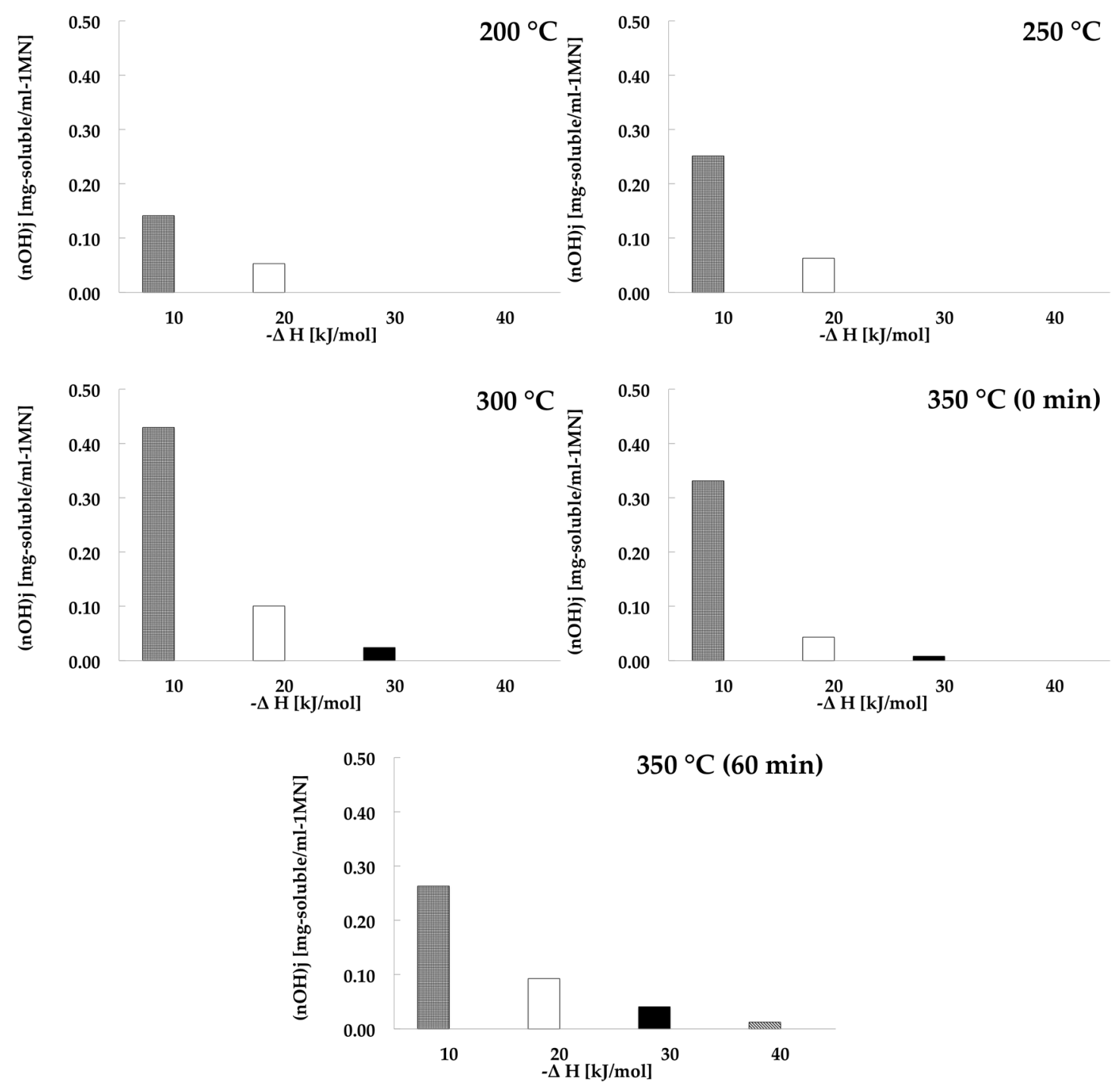

娄 $\mathrm{OH}-\pi \quad \square$ self-associated $\mathrm{OH}$ n-mers $\quad$ OH-ether $\mathbb{O}$ tightly bound cyclic $\mathrm{OH}$ tetramers

Figure 6. The relationship between the amount and the strength of $\mathrm{OH}$-associated hydrogen bonds $(\mathrm{OH}-\pi$, self-associated $\mathrm{OH}$ n-mers, $\mathrm{OH}$-ether, and tightly bound cyclic-OH tetramers) at each treatment temperature for the RS Solvent-soluble. 
Figure 7 shows the estimated amount of the $\mathrm{OH}$-associated hydrogen bonds at the different treatment conditions. At all treatment conditions, the amount of $\mathrm{OH}-\pi$ hydrogen bonds was greater than for the other $\mathrm{OH}$ groups. $\mathrm{OH}-\pi$ hydrogen bonds, along with those for the self-associated $\mathrm{OH}$ $\mathrm{n}$-mers, were the only hydrogen bonds to be measured in all treatment conditions. These hydrogen bonds increased with temperature until $300{ }^{\circ} \mathrm{C}$ and were then observed to decrease at $350{ }^{\circ} \mathrm{C}(0 \mathrm{~min})$. However, for the prolonged residence time at $350^{\circ} \mathrm{C}$, the amount of $\mathrm{OH}-\pi$ hydrogen bonds decreased further, while the hydrogen bonds for the self-associated $\mathrm{OH}$ n-mers were observed to increase. The hydrogen bonds associated with $\mathrm{OH}$-ether were first measured at $300{ }^{\circ} \mathrm{C}$ and decreased in number at $350^{\circ} \mathrm{C}(0 \mathrm{~min})$. However, like the self-associated $\mathrm{OH}$ n-mers, the amount of the $\mathrm{OH}$-ether hydrogen bonds was seen to increase slightly during the prolonged residence time at $350{ }^{\circ} \mathrm{C}$. The hydrogen bonds associated with the tightly bound cyclic-OH tetramers were only measured at the prolonged residence time at $350^{\circ} \mathrm{C}$, and not in great number.

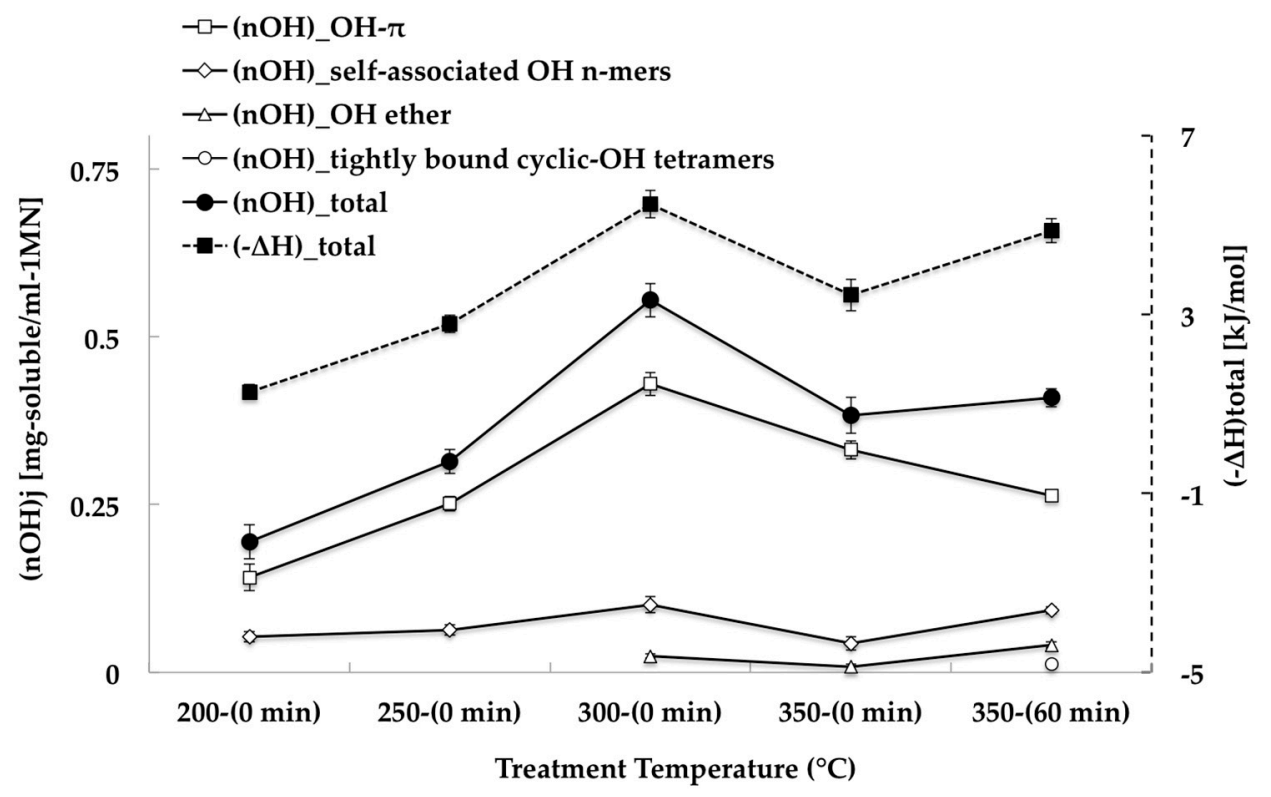

Figure 7. The amount of each $\mathrm{OH}$-associated hydrogen bonding group $\left(n_{\mathrm{OH}}\right)_{\mathrm{j}}$, the total number of hydrogen bonds $\left(n_{\mathrm{OH}}\right)_{\text {total }}$, and the total enthalpy for the formation $(-\Delta \mathrm{H})_{\text {total }}$ for all of the $\mathrm{OH}$-associated hydrogen bonds at each treatment temperature.

Figure 7 also shows the total number of hydrogen bonds associated with $\mathrm{OH}$ groups, as well as the total enthalpy for the formation of these bonds. Both the total number of hydrogen bonds and the total change in the enthalpy of formation were observed to increase from 200 to $300^{\circ} \mathrm{C}$, and then decrease at $350{ }^{\circ} \mathrm{C}(0 \mathrm{~min})$. For the prolonged residence time at $350{ }^{\circ} \mathrm{C}$, the total enthalpy was observed to increase slightly, while the total number of hydrogen bonds remained relatively unchanged. However, in the same treatment conditions, changes were observed in the number of hydrogen bonds for the different $\mathrm{OH}$ groups. In combination with the observed increase in the total change in enthalpy, this suggests a release of the hydrogen bonds associated with the self-associated $\mathrm{OH}$ n-mers, the $\mathrm{OH}$-ether, and the tightly bound cyclic-OH tetramers groups, which all experienced an increase during this treatment condition.

The measured increase in the amount of hydrogen bonds related to $\mathrm{OH}-\pi$ and the self-associated $\mathrm{OH}$ n-mers, in combination with the observed increase in the total change in the enthalpy for the same treatment conditions, suggest that the hydrogen bonds for these two groups were released. Research by Miura et al. reported that the total number of hydrogen bonds and consequently the total change in enthalpy decreased when $\mathrm{H}_{2} \mathrm{O}$ is produced during heat treatment [49]. This suggests that the main removal of $\mathrm{H}_{2} \mathrm{O}$ in DSE of RS occurred from 300 to $350{ }^{\circ} \mathrm{C}$ (0 min). Similarly, the decrease in the hydrogen bonds associated with $\mathrm{OH}-\pi$ and the increase in the total change in enthalpy over the 
prolonged residence time at $350{ }^{\circ} \mathrm{C}$ also suggests that the release of $\mathrm{H}_{2} \mathrm{O}$ molecules is occurring during this period. This is in agreement with other research that has found that the increasing residence time increases the removal of water [18].

From the quantitative results obtained in this work, the schematic in Figure 8 was postulated for the reaction process of DSE of RS. Specifically, the DSE process was divided by temperature range into three stages: From 200 to $300{ }^{\circ} \mathrm{C}$, from 300 to $350{ }^{\circ} \mathrm{C}(0 \mathrm{~min})$, and during the prolonged residence time of $60 \mathrm{~min}$ at $350{ }^{\circ} \mathrm{C}$. The first stage was characterized by the release of hydrogen bonds via dehydration and the presence of aromatic compounds. The second stage was marked by the removal of the main oxygen-containing groups $\left(\mathrm{H}_{2} \mathrm{O}, \mathrm{CO}\right.$, and $\left.\mathrm{CO}_{2}\right)$ through dehydration and decarboxylation, and the occurrence of aromatization. The third stage occurred during the prolonged residence time at $350{ }^{\circ} \mathrm{C}$ (0 to $\left.60 \mathrm{~min}\right)$, and was characterized by aromatization and dehydration reactions. At all stages, dehydration and the presence of aromatic $\mathrm{C}=\mathrm{C}$ groups were observed. This indicates that intramolecular reactions were the predominant mechanism for dehydration in RS DSE. This also signifies that polymerization of RS during the DSE process was suppressed and that the final product is composed of smaller molecular compounds. The suggestion of dehydration along with the observed presence of aromatic $\mathrm{C}=\mathrm{C}$ bonds at each stage clarified that intramolecular reactions were the dominant process reactions among hydrogen bonds of RS during DSE.

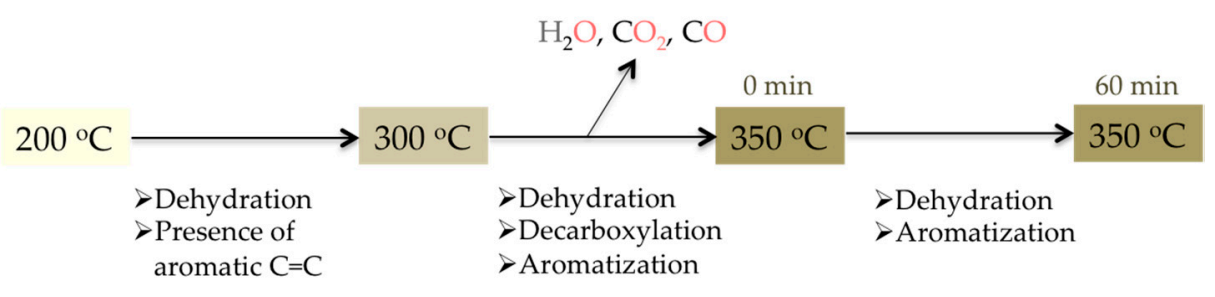

Figure 8. Schematic postulated for the reaction process of the DSE of RS.

\section{Conclusions}

Previous investigations concerning the reaction process for degradative solvent extraction (DSE) of biomass have focused on characterizing the composition of the solid and gas components of the initial reactants and final products. The objective of this study was to provide additional information by analyzing the composition of the liquid state product (the Solvent-soluble) from the DSE of rice straw (RS) in order to further clarify the DSE process mechanism. Analyses were performed under the same conditions as those of a normal DSE system, with no physical or chemical modifications made to the samples. Liquid membrane-FTIR, which was proposed previously for the analysis of the RS DSE process mechanism, was used again with improved experimental conditions to reduce the noise in the water vibrational region. The obtained IR spectra possessed increased peak resolution and allowed for increased quantitative analysis.

DSE of RS was performed in batches at $200,250,300$, and $350{ }^{\circ} \mathrm{C}$ with 0 min residence times and at $350{ }^{\circ} \mathrm{C}$ with a $60 \mathrm{~min}$ residence time. Analysis of the measured IR spectra identified three distinct stages in the DSE of RS reaction process. The first stage, between 200 and $300{ }^{\circ} \mathrm{C}$, suggested the occurrence of dehydration and the presence of aromatic $\mathrm{C}=\mathrm{C}$ compounds. The second stage ( 300 to $350{ }^{\circ} \mathrm{C}$ at $\left.0 \mathrm{~min}\right)$ was characterized by the removal of the main oxygen-containing groups $\left(\mathrm{H}_{2} \mathrm{O}\right.$, $\mathrm{CO}$, and $\mathrm{CO}_{2}$ ) as well as the occurrence of dehydration, decarboxylation, and aromatization reactions. The third stage occurred during the prolonged residence time at $350{ }^{\circ} \mathrm{C}$ ( 0 to $\left.60 \mathrm{~min}\right)$. The observed changes in the functional groups during this stage suggested the occurrence of aromatization and dehydration reactions. This indicates that intramolecular reactions were the predominant mechanism for dehydration in RS DSE. This also signifies that polymerization of RS during the DSE process was suppressed and that the final product is composed of smaller molecular compounds.

This demonstrates that liquid membrane-FTIR can provide quantitative information regarding the reaction process of RS DSE, and suggests its applicability in the analysis of other solvent-carbon based interactions. However, the results show that liquid membrane-FTIR is not suitable in analyzing 
the structural dependence of $\mathrm{CH}$ bond absorptivity of the Solvent-soluble when using a $\mathrm{C}-\mathrm{H}$ bond-containing solvent. Therefore, the identification of a new, more suitable solvent is required for the reliable analysis of $\mathrm{C}-\mathrm{H}$ bonds in the Solvent-soluble. Additionally, all available analytical techniques should be employed for the verification and further elucidation of the RS DSE process mechanism, with liquid membrane-FTIR used to provide additional information.

Author Contributions: Conceptualization, W.K.; data curation, W.K.; formal analysis, W.K.; project administration, W.K.; methodology, W.K.; writing—original draft, W.K.; writing-review \& editing, W.K., H.Z., R.A., T.K., and H.O.

Funding: This research received no external funding.

Conflicts of Interest: The authors declare no conflict of interest.

\section{Appendix A}

Table A1. Peak assignments of IR spectra of the oxygen-containing groups in this study [49,63-70].

\begin{tabular}{|c|c|c|c|c|c|}
\hline No. & $\begin{array}{c}\text { Theoretical } \\
\text { Band Centre } \\
\left(\mathrm{cm}^{-1}\right)\end{array}$ & $\begin{array}{c}\text { Wavenumber } \\
\text { at Band Centre } \\
\left(\mathrm{cm}^{-1}\right)^{*}\end{array}$ & $\begin{array}{l}\text { Deviation } \\
\left(\mathrm{cm}^{-1}\right)^{* *}\end{array}$ & Peak Assignments & References \\
\hline 1 & 3540 & 3547.2 & \pm 23.0 & $\mathrm{OH}-\pi$ hydrogen bonds & {$[49,63]$} \\
\hline 2 & 3400 & 3424.8 & \pm 25.9 & self-associated $n$-mers $(n>3)$ & {$[49,63]$} \\
\hline 3 & 3290 & 3290.4 & \pm 16.3 & $\mathrm{OH}$-ether $\mathrm{O}$ hydrogen bonds & {$[49,63]$} \\
\hline 4 & 3150 & 3208.5 & \pm 5.0 & tightly bound cyclic $\mathrm{OH}$ tetramers & {$[49,63]$} \\
\hline 5 & 1800 & 1803.7 & \pm 5.8 & asymmetric anhydride $(-\mathrm{C}(\mathrm{O}) 2 \mathrm{O}-)$ & {$[64,65]$} \\
\hline 6 & 1770 & 1757.1 & \pm 13.7 & ester $(-\mathrm{COO})$ & [66-69] \\
\hline 7 & 1740 & 1762.2 & \pm 20.0 & aldehydes $(-\mathrm{CHO})$ & {$[64,65]$} \\
\hline 8 & 1710 & 1712.1 & \pm 2.7 & carboxylic acids $(\mathrm{COOH})$ & {$[66-70]$} \\
\hline 9 & 1670 & 1689.4 & \pm 6.3 & conjugated carbonyl (CO) & {$[66-70]$} \\
\hline 10 & 1650 & 1630 & \pm 6 & highly conjugated carbonyl (CO) & {$[69,70]$} \\
\hline 11 & 1607 & 1596.4 & \pm 0.3 & aromatics $\mathrm{C}=\mathrm{C}$ & {$[49,66,69,70]$} \\
\hline 12 & 1580 & 1581.8 & \pm 2.7 & aromatics $\mathrm{C}=\mathrm{C}$ & {$[49,69,70]$} \\
\hline 13 & 1560 & 1566.4 & \pm 0.9 & aromatics $\mathrm{C}=\mathrm{C}$ & {$[49,69,70]$} \\
\hline
\end{tabular}

$*, * *$ : Wavenumber of fitting and deviation obtained from the average and standard deviation of the fitting results of all treatment temperatures (peak center shifts with different treatment temperature).

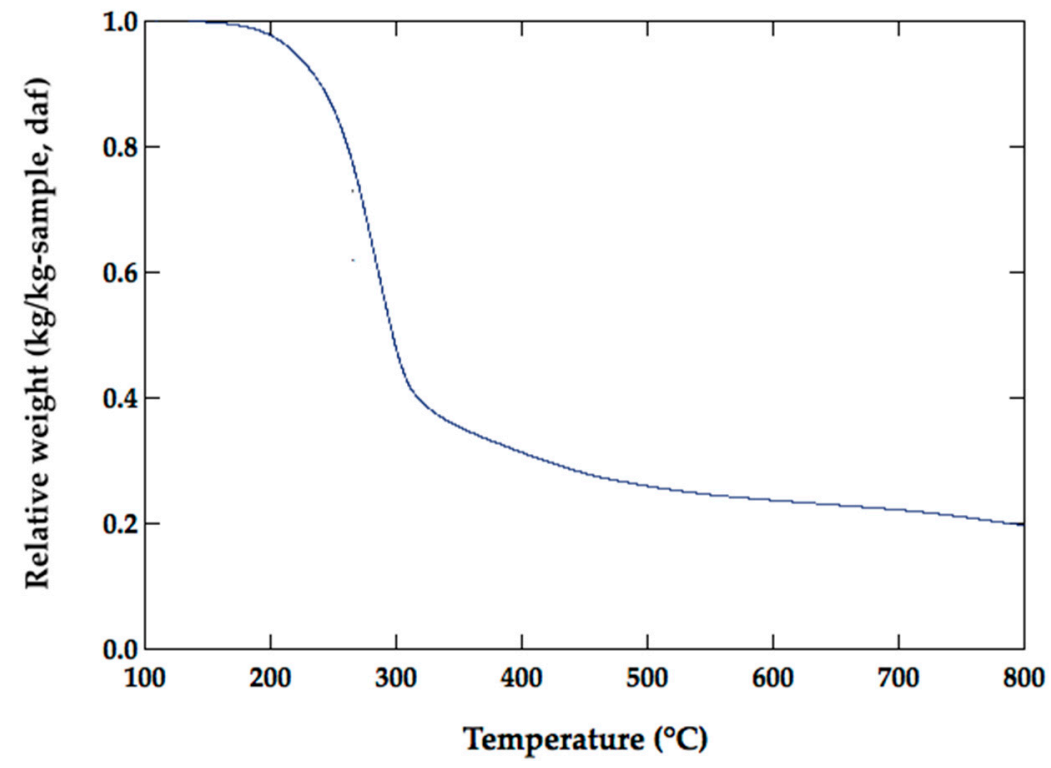

Figure A1. Thermogravimetric (TG) curve of rice straw.

\section{References}

1. Edenhofer, O.; Pichs-Madruga, R.; Sokona, Y.; Seyboth, K.; Kadner, S.; Zwickel, T.; Eickemeier, P.; Hansen, G.; Schlömer, S.; Von Stechow, C.; et al. Intergovernmental Panel on Climate Change (IPCC); Special Report on 
Renewable Energy SOURCES and Climate Change Mitigation. Summary for Policy-Makers; Cambridge University Press: Cambridge, UK, 2011.

2. González, J.F.; Ledesma, B.; Alkassir, A.; González, J. Study of the influence of the composition of several biomass pellets on the drying process. Biomass Bioenergy 2011, 35, 4399-4406. [CrossRef]

3. Bridgwater, A.V. Renewable fuels and chemicals by thermal processing of biomass. Chem. Eng. J. 2003, 91, 87-102. [CrossRef]

4. Zhou, C.H.; Xia, X.; Lin, C.X.; Tong, D.S.; Beltramini, J. Catalytic conversion of lignocellulosic biomass to fine chemicals and fuels. Chem. Soc. Rev. 2011, 40, 5588-5617. [CrossRef] [PubMed]

5. Taarning, E.; Osmundsen, C.M.; Yang, X.B.; Voss, B.; Andersen, S.I.; Christensen, C.H. Zeolite-catalyzed biomass conversion to fuels and chemicals. Energy Environ. Sci. 2011, 4, 793-804. [CrossRef]

6. Kwietniewska, E.; Tys, J. Process characteristics, inhibition factors and methane yields of anaerobic digestion process, with particular focus on microalgal biomass fermentation. Renew. Sustain. Energy Rev. 2014, 34, 491-500. [CrossRef]

7. Limayem, A.; Ricke, S.C. Lignocellulosic biomass for bioethanol production: Current perspectives, potential issues and future prospects. Prog. Energy Combust. Sci. 2012, 38, 449-467. [CrossRef]

8. Sharma, A.; Pareek, V.; Zhang, D. Biomass pyrolysis-A review of modelling, process parameters and catalytic studies. Renew. Sustain. Energy Rev. 2015, 50, 1081-1096. [CrossRef]

9. Mckendry, P. Energy production from biomass (part 2): Conversion Technologies. Bioresour. Technol. 2002, 83, 47-54. [CrossRef]

10. Liu, Y.; Aziz, M.; Fushimi, C.; Kansha, Y.; Mochidzuki, K.; Kaneko, S.; Tsutsumi, A.; Yokohama, K.; Myoyo, K.; Oura, K.; et al. Exergy analysis of biomass drying based on self-heat recuperation technology and its application to industry: A simulation and experimental study. Ind. Eng. Chem. Res. 2012, 51, 9997-10007. [CrossRef]

11. Miura, K.; Mae, K.; Shindo, H.; Ashida, R.; Ihara, T. Extraction of low rank coals by coal derived oils at 350 ${ }^{\circ} \mathrm{C}$ for producing clean fuels. J. Chem. Eng. Jpn. 2003, 36, 742-750. [CrossRef]

12. Morimoto, M.; Nakagawa, H.; Miura, K. Conversion of a wide range of low-rank coals into upgraded coals and thermoplastic extracts having similar chemical and physical properties using degradative hydrothermal extraction. Energy Fuels 2010, 24, 3060-3065. [CrossRef]

13. Li, S.-X.; Chen, C.-Z.; Li, M.-F.; Xiao, X. Torrefaction of corncob to produce charcoal under nitrogen and carbon dioxide atmospheres. Bioresour. Technol. 2018, 249, 348-353. [CrossRef] [PubMed]

14. Li, X.; Zhu, X.-Q.; Xiao, L.; Ashida, R.; Miura, K.; Luo, G.-Q.; Yao, H. Degradative solvent extraction of demineralized and ion-exchanged low-rank coals. J. Fuel Chem. Technol. 2014, 42, 897-904. [CrossRef]

15. Zhu, X.; Li, X.; Xiao, L.; Zhang, X.; Tong, S.; Wu, C.; Ashida, R.; Liu, W.; Miura, K.; Yao, H. Novel carbon-rich additives preparation by degradative solvent extraction of biomass wastes for coke-making. Bioresour. Technol. 2016, 207, 85-91. [CrossRef] [PubMed]

16. Wannapeera, J.; Li, X.; Worasuwannarak, N.; Ashida, R.; Miura, K. Production of high-grade carbonaceous materials and fuel having similar chemical and physical properties from various types of biomass by degradative solvent extraction. Energy Fuels 2012, 26, 4521-4531. [CrossRef]

17. Zhu, X.-Q.; Zhang, Z.; Zhou, Q.-X.; Cai, T.; Qiao, E.; Li, X.; Yao, H. Upgrading and multistage separation of rice straw by degradative solvent extraction. J. Fuel Chem. Technol. 2015, 43, 422-428. [CrossRef]

18. Zhu, X.; Xue, Y.; Li, X.; Zhang, Z.; Sun, W.; Ashida, R.; Miura, K.; Yao, H. Mechanism study of degradative solvent extraction of biomass. Fuel 2016, 165, 10-18. [CrossRef]

19. Trirat, M.; Wannapeera, J.; Supachai, J.; Nakorn, W.; Ohgaki, H.; Miura, K. Effect of solvent on the degradative solvent extraction of low rank coal. Energy Fuels 2017, 31, 11954-11962.

20. Li, X.; Zhu, X.Q.; Okuda, K.; Zhang, Z.; Ashida, R.; Yao, H.; Miura, K. Preparation of carbon fibers from low-molecular-weight compounds obtained from low-rank coal and biomass by solvent extraction. New Carbon Mater. 2017, 32, 41-47. [CrossRef]

21. Wannapeera, J.; Ashida, R.; Ohgaki, H.; Miura, K. Production of carbon fiber and activated carbon fiber from the extract produced from the degradative solvent extraction of biomass. In Proceedings of the International Conference on Coal Science \& Technology and 2017 Australia-China Symposium on Energy, Beijing, China, 25-29 September 2017.

22. Ashida, R.; Takahashi, R.; Kawase, M.; Miura, K. Upgrading Mechanism in Degradative Solvent Extraction of Biomass Wastes. In Proceedings of the 12th EMSES Conference, Krabi, Thailand, 11-14 June 2015. 
23. Painter, P.C.; Snyder, R.W.; Starsinic, M.; Coleman, M.M.; Kuehn, D.W.; Davis, A. Concerning the application of FT-IR to the study of coal: A critical assessment of band assignments and the application of spectral analysis programs. Appl. Spectrosc. 1981, 35, 475-485. [CrossRef]

24. Painter, P.C.; Starsinic, M.; Squires, E.; Davis, A. Concerning the $1600 \mathrm{~cm}^{-1}$ region in the IR spectrum of coal. Fuel 1983, 62, 742-744. [CrossRef]

25. Solomon, P.R.; Carangelo, R.M. FT-IR analysis of coal: 2. Aliphatic and aromatic hydrogen concentration. Fuel 1988, 67, 949-959. [CrossRef]

26. Sobkowiak, M.; Painter, P.A. A comparison of drift and $\mathrm{KBr}$ pellet methodologies for the quantitative analysis of functional groups in coal by infrared spectroscopy. Energy Fuels 1995, 9, 359-363. [CrossRef]

27. Jiang, X.; Ellis, N.; Shen, D.K.; Jiang, J.; Dai, W.; Zhong, Z. Thermogravimetric-FTIR analysis of pyrolysis of pyrolytic lignin extracted from bio-oil. Chem. Eng. Technol. 2011, 35, 827-833.

28. Liu, Q.; Wang, S.; Zheng, Y.; Luo, Z.; Cen, K. Mechanism study of wood lignin pyrolysis by using TG-FTIR analysis. J. Anal. Appl. Pyrolysis 2008, 82, 170-177.

29. Luo, S.; Bao, G.; Wang, H.; Li, F.; Li, Y. TG-DSC-FTIR analysis of cyanobacteria pyrolysis. Phys. Procedia 2012, 33, 657-662.

30. Zhou, H.; Meng, A.H.; Long, Y.Q.; Li, Q.H.; Zhang, Y.G. Interactions of municipal solid waste components during pyrolysis a TG-FTIR study. J. Anal. Appl. Pyrolysis 2014, 108, 19-25.

31. Liu, Q.; Zhong, Z.P.; Wang, S.R.; Luo, Z.Y. Interactions of biomass components during pyrolysis: A TG-FTIR study. J. Anal. Appl. Pyrolysis 2011, 90, 213-218.

32. Bassilakis, R.; Carangelo, R.M.; Wojtowicz, M.A. TG-FTIR analysis of biomass pyrolysis. Fuel 2001, 80, 1765-1786. [CrossRef]

33. Tucker, M.P.; Nguyen, Q.A.; Eddy, F.P.; Kadam, K.L.; Gedvilas, L.M.; Webb, J.D. Fourier transform infrared quantitative analysis of sugars and lignin in pretreated softwood solid residues. In Twenty-Second Symposium on Biotechnology for Fuels and Chemicals; Humana Press: Totowa, NJ, USA, 2001; pp. 51-61.

34. Fengel, D. Possibilities and limits of FTIR spectroscopy for the characterization of cellulose. Pt. 2. Comparison of various pulps. Papier (Germany, FR) 1991, 45, 97-102.

35. Kataoka, Y.; Kondo, T. FT-IR microscopic analysis of changing cellulose crystalline structure during wood cell wall formation. Macromolecules 1998, 31, 760-764. [CrossRef]

36. Faix, O. Classification of lignins from different botanical origins by FT-IR spectroscopy. Holzforsch. Int. J. Boil. Chem. Phys. Technol. Wood 1991, 45, 21-28. [CrossRef]

37. Marchessault, R.H. Application of infrared spectroscopy to cellulose and wood polysaccharides. Pure Appl. Chem. 1962, 5, 107-130. [CrossRef]

38. Bertie, J.E.; Keefe, C.D.; Jones, R.N. Infrared intensities of liquids VIII. Accurate baseline correction of transmission spectra of liquids for computation of absolute intensities, and the $1036 \mathrm{~cm}^{-1}$ band of benzene as a potential intensity standard. Can. J. Chem. 1991, 69, 1609-1618. [CrossRef]

39. Porter, J.M.; Jeffries, J.B.; Hanson, R.K. Mid-infrared absorption measurements of liquid hydrocarbon fuels near $3.4 \mu \mathrm{m}$. J. Quant. Spectrosc. Radiat. Transf. 2009, 110, 2135-2147. [CrossRef]

40. Dong, A.; Huang, P.; Caughey, W.S. Protein secondary structures in water from second-derivative amide I infrared spectra. Biochemistry 1990, 29, 3303-3308. [CrossRef]

41. Yu, S.; Wuu, A.; Basu, R.; Holbrook, M.R.; Barrett, A.D.; Lee, J.C. Solution structure and structural dynamics of envelope protein domain III of mosquito-and tick-borne flaviviruses. Biochemistry 2004, 43, 9168-9176. [CrossRef] [PubMed]

42. Watcharakorn, K.; Trirat, M.; Janewit, W.; Zen, H.; Kii, T.; Miura, K.; Ohgaki, H. Proposal of liquid membrane-FTIR spectroscopy to quantify the oxygen content in soluble fraction of degradative solvent-extraction. Int. J. Exp. Spectrosc. Tech. 2017, 2, 010.

43. Watcharakorn, K.; Janewit, W.; Zen, H.; Kii, T.; Miura, K.; Ohgaki, H. The mechanism study of degradative solvent extraction of biomass by liquid membrane-Fourier Transform Infrared spectroscopy. Int. J. Phys. Math. Sci. 2018, 12, 9-13.

44. Drago, R.S.; Epley, T.D. Enthalpies of hydrogen bonding and changes in hydroxy frequency shifts for a series of adducts with substituted phenols. J. Am. Chem. Soc. 1969, 91, 2883-2890. [CrossRef]

45. Larsen, J.W.; Gurevich, I.; Glass, A.S.; Stevenson, D.S. A method for counting the hydrogen-bond cross-links in coal. Energy Fuels 1996, 10, 1269-1272. [CrossRef] 
46. Chen, C.; Gao, J.; Yan, Y. Observation of the type of hydrogen bonds in coal by FTIR. Energy Fuels 1998, 12, 446-449. [CrossRef]

47. Miura, K.; Kazuhiro, M.; Fumi-aki, M. A new method to estimate hydrogen bonds in coal by utilizing FTIR and DSC. Am. Chem. Soc. Fuel Div. 1997, 42, 209-213.

48. Miura, K.; Mae, K.; Li, W.; Kusakawa, T.; Kumano, A. In situ FT-IR measurement of the change in hydrogen bonding of coal through heat treatment. In Abstracts of Papers of the American Chemical Society; American Chemical Society: Washington, DC, USA, 1999; Volume 218, p. U612.

49. Miura, K.; Mae, K.; Li, W.; Kusakawa, T.; Morozumi, F.; Kumano, A. Estimation of hydrogen bond distribution in coal through the analysis of $\mathrm{OH}$ stretching bands in diffuse reflectance infrared spectrum measured by in-situ technique. Energy Fuels 2001, 15, 599-610. [CrossRef]

50. Barry, B.A.; Brahmachari, U.; Guo, Z. Tracking reactive water and hydrogen-bonding networks in photosynthetic oxygen evolution. Acc. Chem. Res. 2017, 50, 1937-1945. [CrossRef] [PubMed]

51. Solomon, P.R. Relation between coal structure and thermal decomposition products. In Coal Structure: Advances in Chemistry Series; Gorbaty, M.L., Ouchim, K., Eds.; ACS: Washington, DC, USA, 1981; Volume 192, Chapter 7; p. 95.

52. Fuller, E.L., Jr.; Smyrl, N.R. Chemistry and structure of coals: Diffuse reflectance IR spectroscopy equipment and techniques. Fuel 1985, 64, 1143-1150. [CrossRef]

53. Kadla, J.F.; Kubo, S. Miscibility and hydrogen bonding in blends of poly (ethylene oxide) and kraft lignin. Macromolecules 2003, 36, 7803-7811. [CrossRef]

54. Kubo, S.; Kadla, J.F. Hydrogen bonding in lignin: A Fourier transform infrared model compound study. Biomacromolecules 2005, 6, 2815-2821. [CrossRef]

55. Poletto, M.; Pistor, V.; Santana, R.M.C.; Zattera, A.J. Materials produced from plant biomass: Part II: Evaluation of crystallinity and degradation kinetics of cellulose. Mater. Res. 2012, 15, 421-427. [CrossRef]

56. Poletto, M.; Zattera, A.J. Materials produced from plant biomass: Part III: Degradation kinetics and hydrogen bonding in lignin. Mater. Res. 2013, 16, 1065-1070. [CrossRef]

57. Arnett, E.M.; Mitchell, E.J.; Murty, T.S.S.R. Basicity. Comparison of hydrogen bonding and proton transfer to some Lewis bases. J. Am. Chem. Soc. 1974, 96, 3875-3891. [CrossRef]

58. Miura, K.; Mae, K.; Ashida, R.; Tamura, T.; Ihara, T. Dewatering of coal through solvent extraction. Fuel 2002, 81, 1417-1422. [CrossRef]

59. Miura, K.; Hasegawa, Y.; Ashida, R. Upgrading of brown coal using solvent extraction at high temperature. In Abstracts of Papers of the American Chemical Society; American Chemical Society: Washington, DC, USA, 2009; Volume 238.

60. Choice of windows materials for transmission sampling of liquids in Mid-IR spectral region. Application Note-0602, Spectroscopic Creativity; PIKE Technologies: Madison, WI, USA. Available online: https:/ /www. piketech.com/skin/fashion_mosaic_blue/application-pdfs/CrystalChoiceForTransmission.pdf (accessed on 1 February 2019).

61. Katsumi, H. FTIR and water. In FTIR Talk Letter; Shimadzu: Kyoto, Japan, 2013; Volume 19, p. 2.

62. Nasse, M.J.; Ratti, S.; Giordano, M.; Hirschmugl, C.J. Demountable liquid/flow cell for in vivo infrared microspectroscopy of biological specimens. Appl. Spectrosc. 2009, 63, 1181-1186. [CrossRef] [PubMed]

63. Painter, P.C.; Sobkowiak, M.; Youtcheff, J. FT-IR study of hydrogen bonding in coal. Fuel 1987, 66, 973-978. [CrossRef]

64. Painter, P.C.; Starsinic, M.; Coleman, M.M. Determination of functional groups in coal by Fourier transform interferometry. In Fourier Transform Infrared Spectroscopy; Ferraro, J.R., Basile, L.J., Eds.; Academic Press: New York, NY, USA, 1985; pp. 169-240.

65. Painter, P.C.; Snyder, R.W. The application of Fourier transform infrared spectroscopy to the characterization of coal structure. Fuel 1979, 58, 301-308. [CrossRef]

66. Supaluknari, S.; Larkins, F.P. An FTIR study of Australian coals: Characterization of oxygen functional groups. Fuel Process. Technol. 1988, 19, 123-140. [CrossRef]

67. Ibarra, J.V.; Munoz, E.; Moliner, R. FTIR study of the evolution of coal structure during the coalification process. Org. Geochem. 1996, 24, 725-735. [CrossRef]

68. Murakami, K.; Shirato, H.; Nishiyama, Y. In situ infrared spectroscopic study of the effects of exchanged cations on the thermal decomposition of a brown coal. Fuel 1997, 76, 655-661. [CrossRef] 
69. Wang, Y.; Wu, J.; Xue, S.; Wang, J.; Zhang, Y. Experimental Study on the Molecular Hydrogen Release Mechanism during Low-Temperature Oxidation of Coal. Energy Fuel 2017, 31, 5498-5506. [CrossRef]

70. Wenhua, G.; Tsunemori, N.; Hirokazu, T.; Akira, O. Analysis of carboxyl group in coal and coal aromaticity by Fourier transform infrared (FT-IR) spectroscopy. Fuel 2009, 88, 139-144.

(c) 2019 by the authors. Licensee MDPI, Basel, Switzerland. This article is an open access article distributed under the terms and conditions of the Creative Commons Attribution (CC BY) license (http:/ / creativecommons.org/licenses/by/4.0/). 